\title{
Relationships among wildfire, prescribed fire, and drought in a fire-prone landscape in the south-eastern United States
}

\author{
Robert N. Addington ${ }^{\mathrm{A}, \mathrm{E}, \mathrm{F}}$, Stephen J. Hudson ${ }^{\mathrm{B}}$, J. Kevin Hiers ${ }^{\mathrm{C}}$, \\ Matthew D. Hurteau ${ }^{\mathrm{D}}$, Thomas F. Hutcherson ${ }^{\mathrm{B}}$, George Matusick ${ }^{\mathrm{A}}$ \\ and James M. Parker ${ }^{\mathrm{B}}$

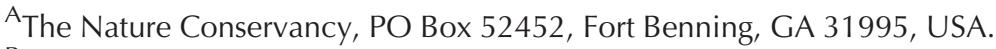 \\ ${ }^{B}$ Directorate of Public Works, Land Management Branch, Building 5884, First Division Road, \\ Fort Benning, GA 31905, USA. \\ CUniversity of the South, Environmental Stewardship, 735 University Avenue, Sewanee, \\ TN 37383, USA. \\ ${ }^{D}$ The Pennsylvania State University, Department of Ecosystem Science and Management, \\ Bigler Road, University Park, PA 16802, USA. \\ EPresent address: The Nature Conservancy, 2424 Spruce Street, Boulder, CO 80302, USA. \\ FCorresponding author. Email: addingtonrob@gmail.com
}

\begin{abstract}
Concern over increasing wildfire activity in the last few decades has prompted increased investment in fuels reduction treatments worldwide. Prescribed fire is a commonly used management tool for reducing fuels and modifying subsequent wildfire dynamics, yet the influence of prescribed fire on wildfire is difficult to evaluate empirically due to the often unpredictable nature of wildfire. In this study we evaluated a 30-year record of wildfire, prescribed fire and drought at Fort Benning, a 74 000-ha military training installation in west-central Georgia, USA. Annual wildfire incidence declined sharply from 1982 to 2012 as prescribed fire hectares increased. Multiple regression models including both prescribed fire and drought (assessed using the Keetch-Byram Drought Index; KBDI) explained $\sim 80 \%$ and $54 \%$ of the variation in annual wildfire incidence and areal extent, respectively. Current- and previous-year prescribed fire were strongly inversely related to current-year wildfire, suggesting that the cumulative area burned by prescription is important in explaining current-year wildfire incidence. Wildfire activity overall (both incidence and areal extent) was highest during drought years when cumulative prescribed fire hectares were low. Our results suggest some inevitability of wildfire during drought, but also provide evidence for the positive effects of sustained landscape-scale prescribed fire in reducing wildfire activity over time.
\end{abstract}

Additional keywords: Fort Benning, fuels reduction, Keetch-Byram Drought Index, longleaf pine.

Received 3 May 2014, accepted 22 April 2015, published online 9 July 2015

\section{Introduction}

Wildfire activity has increased in many parts of the world in recent decades, raising public concern and highlighting the need for cohesive strategies aimed at fuels management, community protection, landscape restoration and public education (USDA Forest Service 2000; Westerling et al. 2006; Butry et al. 2010; Stephens et al. 2012; McCaw 2013). Of particular concern are high-severity wildfires burning in ecological systems historically characterised by frequent, low-intensity surface fire. These ecological systems have been the focus of fuels reduction and restoration treatments in recent years, as current wildfire trends are believed to be due in large part to fuel accumulation that has occurred with fire exclusion (Marshall et al. 2008; Schwilk et al. 2009; McCaw 2013; Stephens et al. 2013).

Fire is a physical process controlled by complex interactions among weather, topography and fuels (Countryman 1972; Brown and Smith 2000; Prestemon et al. 2013). Dry atmospheric conditions combined with high winds and low fuel moistures often represent the criteria under which wildfires occur, with subsequent fire behaviour dictated largely by weather, topography and fuel loads (Brown and Smith 2000; Prestemon et al. 2013). Both prescribed fire and past wildfire have been shown to be important in influencing current wildfire ignitions, areal extent and intensity, by regulating fuels (Prestemon et al. 2002; Mercer and Prestemon 2005; Mercer et al. 2007; Mitchell et al. 2009). For this reason prescribed fire has become an important management tool for fuels reduction in fire-prone ecosystems worldwide. However, the influence of prescribed fire on current wildfire is difficult to measure directly and most studies rely on model simulations or opportunistic evaluation of wildfires burning into areas previously burned by prescribed fire (Davis and Cooper 1963; Fernandes and Botelho 2003; Finney et al. 2005; Haywood 
2009; Fulé et al. 2012; Prichard and Kennedy 2014). As a result many studies evaluating relationships between prescribed fire and wildfire are limited in both temporal and spatial extent.

Military installations in the south-eastern (SE) United States provide a unique opportunity to assess trends in both prescribed fire and wildfire over time because they often have active prescribed fire programmes as well as frequent occurrence of wildfire due to military training activities. Fort Benning is a 74 000-ha Unites States Army training installation in westcentral Georgia, which currently burns $\sim 12000$ ha annually by prescription and has maintained records of both prescribed fire and wildfire since the early 1980s. In this study we evaluated relationships among prescribed fire (spatial extent of area burned annually by prescription), wildfire incidence (number of unplanned ignitions annually) and wildfire area burned (spatial extent of area burned annually by wildfire) at Fort Benning from 1982 to 2012. We also factored in the influence of weather on wildfire by incorporating drought and fire-related weather indices within a multiple regression framework. Our primary objective was to evaluate whether trends over time in wildfire incidence and areal extent are related to prescribed fire activities at Fort Benning, and the degree to which these relationships are influenced by weather patterns, particularly drought.

\section{Methods}

Study area

Fort Benning lies within the South-eastern Plains Ecoregion of the SE United States and is characterised by gentle, rolling topography with elevation ranging from 58 to $226 \mathrm{~m}$ above sea level (USAIC 2006). The climate of the area is temperate with mild winters and hot, humid summers. Precipitation averages $1295 \mathrm{~mm}$ annually (USAIC 2006).

Fort Benning is characterised by diverse vegetation types ranging from pine-dominated uplands to hardwood-dominated lower slopes and bottomlands (USAIC 2006). Common pine species include loblolly (Pinus taeda L.), shortleaf ( $P$. echinata Mill.) and longleaf ( $P$. palustris Mill.) pines, and common hardwoods include oaks (Quercus spp.), hickories (Carya spp.) and sweetgum (Liquidambar styraciflua L.). Upland areas were historically characterised by longleaf pine and mixed-pine forests and woodlands, maintained by frequent fire every 1-5 years (Frost and Langley 2009). Remnant vegetation structure suggestive of historical conditions still exists at Fort Benning, though most of the current vegetation represents recovery from agricultural and other land uses that accompanied European settlement of the area beginning in the 1830s (USAIC 2006).

Despite historically frequent fire and a social culture of 'woods burning' in the SE United States, fire suppression policies were adopted in the 1920s (Pyne 1982). Around this same time, the natural role of fire was also being recognised, especially in longleaf pine ecosystems (Stoddard 1931; Chapman 1932). At Fort Benning, prescribed fire has been used since the mid-1950s for various purposes, including fuels reduction to reduce the severity of wildfires caused by military training (USAIC 2006). Infantry training occurs throughout Fort Benning and ignitions due to flares, smoke grenades and live ordinance are dispersed throughout the landscape. In the 1990s fire management objectives began to incorporate ecological objectives such as habitat improvement for the federally endangered red-cockaded woodpecker (Picoides borealis) (USAIC 2006). Both increasing the annual area burned by prescribed fire and instituting a 2-3-year fire return interval became primary objectives at this time.

\section{Data preparation and analysis}

Fort Benning's Directorate of Public Works Land Management Branch maintains records of wildfire occurrence and areal extent of both wildfire and prescribed fire dating back to 1982 . Currently these records are maintained in geospatial format with detailed information regarding dates, locations and area burned both by wildfire and prescribed fire. Earlier records (1980s era) are less detailed but still provide useful information about annual wildfire frequency and areal extent of both wildfire and prescribed fire. As we were interested in evaluating broad-scale effects of prescribed fire on wildfire dynamics over time, we summarised the data by year (from 1982 to 2012) over the entire spatial extent of the military reservation. All fire records are organised by United States government fiscal year (1 October30 September) as opposed to calendar year. We did not have detailed information about ignition sources (natural vs. human caused) and therefore aggregated across sources. The majority of unplanned ignitions, however, are believed to be human caused, related to military training.

We obtained meteorological records from the USA National Oceanic and Atmospheric Administration National Climatic Data Center, using records from the West Central Georgia Climate Division as well as individual Remote Automated Weather Stations in the vicinity of Fort Benning. We used weather stations at Newnan, Plains and Byromville, Georgia (all within a $125-\mathrm{km}$ radius) because they contained the most complete records throughout the period of interest, from 1982 to 2012. We processed weather data using FireFamily Plus (v. 4.1), a USA Forest Service software application capable of synthesising and outputting fire-related weather variables (Bradshaw and McCormick 2000). We included two commonly used drought indices in our analysis: the Palmer Drought Severity Index (PDSI; Palmer 1965) and the Keetch-Byram Drought Index (KBDI; Keetch and Byram 1968). The PDSI typically ranges from -6 to +6 , with negative values indicating drought and positive values indicating periods of above-average precipitation, whereas the KBDI ranges from 0 to 800 , with 800 indicating severe drought. We also included two other fire weather and fire behaviour indices, the Energy Release Component (ERC) and the Canadian Forest Fire Weather Index (FWI), to account for weather variables such as air temperature and relative humidity that influence fuel moistures. We exported daily records from FireFamily Plus and averaged them by fiscal year to correspond with fire records.

We used multivariate regression analysis in an information theoretic framework to evaluate the influence of prescribed fire, past wildfire and weather variables on wildfire incidence and areal extent. We modelled wildfire incidence as a negative binomial distribution because it is a count variable (Mercer and Prestemon 2005; Prestemon et al. 2013). We also tested and rejected a Poisson model because of over-dispersion. We added explanatory variables to the model consecutively through a 


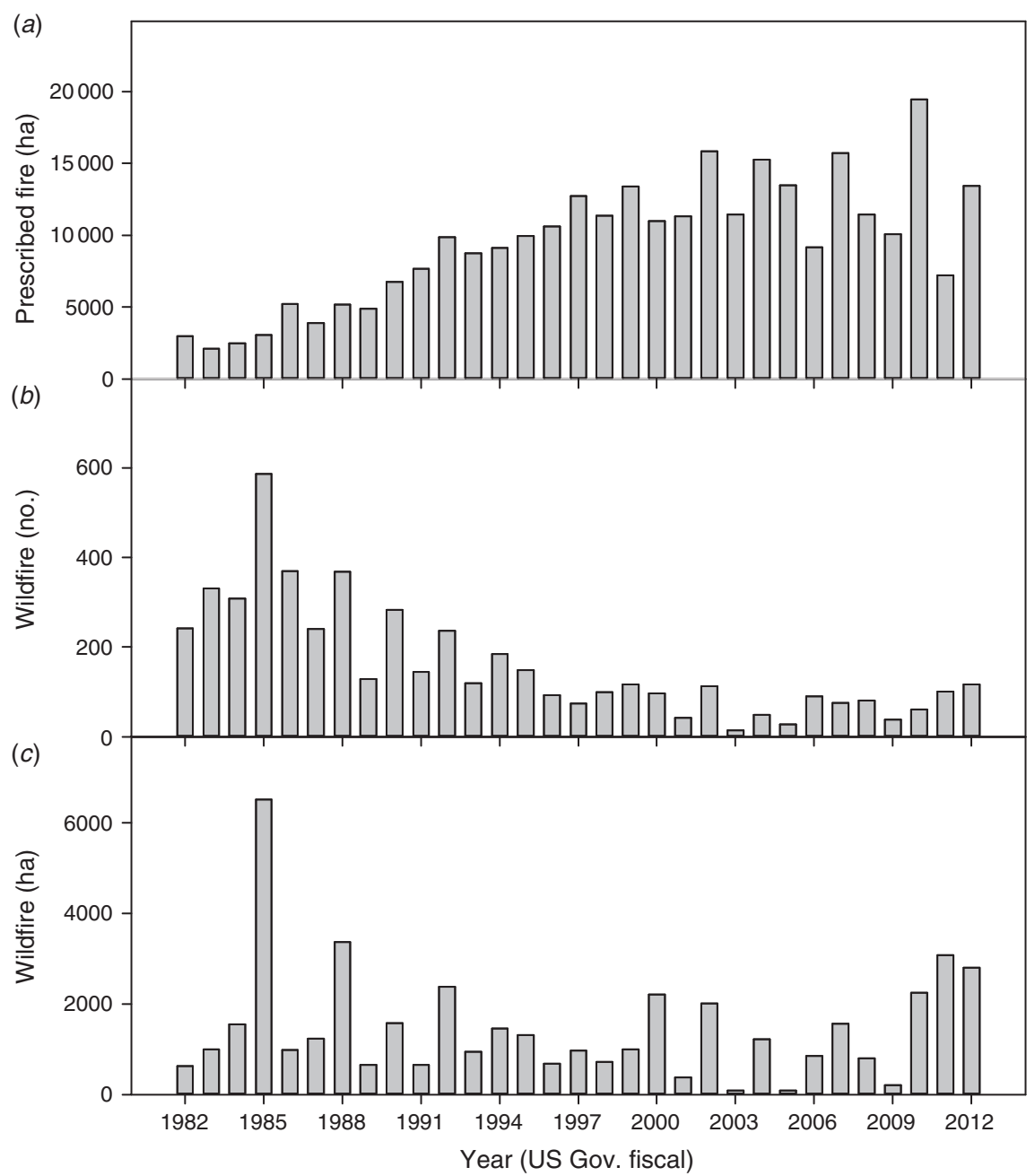

Fig. 1. Trends in (a) prescribed fire area (hectares burned), (b) wildfire incidence (number of unplanned ignitions) and $(c)$ wildfire area (hectares burned by wildfire) from 1982 to 2012 at Fort Benning, GA.

forward selection process and used Akaike's Information Criterion for small sample sizes (AICc) to evaluate the fit of each model (Burnham and Anderson 2002). The full suite of explanatory variables tested included current and previous prescribed fire area (lagged up to 10 years), previous wildfire incidence and area burned (also lagged to 10 years), and PDSI, KBDI, ERC and the FWI. Annual averages and annual maximums were evaluated for the weather variables, as were interactions among explanatory variables. We detected serial correlation in wildfire incidence by evaluating residual plots of the relationship between wildfire incidence and time. We included lagged wildfire incidence in our model both to mitigate serial correlation and because of its predictive ability, as described more below. Variance inflation factors (VIFs) were used to assess collinearity and variables with high VIFs were removed from the model. We used Cook's D for outlier analysis but none were detected. We calculated McFadden's pseudo- $R^{2}$ using the loglikelihood of the full model $v s$. a null (intercept-only) model to evaluate goodness of fit. Wildfire areal extent was analysed similarly to wildfire incidence, though was modelled as a normal distribution following log-transformation. For this model, we tested but did not find serial correlation using the DurbinWatson statistic. Analyses were conducted using the GENMOD procedure in SAS (SAS v. 9.3; SAS Institute, Inc., Cary, NC).

\section{Results}

From 1982 to 2012, there was an overall increase in hectares burned by prescribed fire corresponding with Fort Benning's increased use of fire for meeting fuels reduction and ecosystem management objectives (Fig. 1a). Wildfire incidence declined over this same period (Fig. 1b). Currently, annual wildfire incidence appears to be stabilising at or below 100 wildfires per year, in contrast to the 300-500 annual wildfires observed earlier in the record. Annual areal extent of wildfires was more variable over time relative to wildfire incidence, and increased in the final 3 years of our record (Fig. 1c), possibly due to Fort Benning's 'let burn' policy, described in more detail below.

Of the regression models evaluated, annual wildfire incidence was most strongly related to the sum of current and previous-year prescribed fire area, previous wildfire incidence 
Table 1. Multiple regression model for wildfire incidence Best fit model predicting annual wildfire incidence (number of wildfires) from previous wildfire incidence, prescribed fire and drought. Functional form of the model is $Y=\exp \left(\beta_{0}+\beta_{1} X 1+\beta_{2} X 2+\beta_{3} X 3\right)$ with a pseudo- $R^{2}$ of 0.80 and $n=28 . X 1=$ prescribed fire ha current year + previous year (lag 1); $X 2=$ current-year Keetch-Byram Drought Index, KBDI; $X 3=\log _{10}$ wildfire incidence lag1 + lag2 + lag3

\begin{tabular}{lclcr}
\hline Term & Coefficient, $\beta$ & Standard error & Wald chi-square & $P$-value \\
\hline Constant & 2.520 & 1.417 & 3.16 & 0.0754 \\
$X 1$ & -0.0000578 & 0.0000190 & 9.27 & 0.0023 \\
$X 2$ & 0.00486 & 0.00109 & 19.70 & $<0.0001$ \\
$X 3$ & 0.327 & 0.146 & 5.02 & 0.0250 \\
\hline
\end{tabular}

and drought (Table 1). The selected model accounted for $80 \%$ of the variation in wildfire incidence, based on a pseudo- $R^{2}$ estimate, and was separated from the next best fitting model, which included the same set of variables except for drought, by $\Delta$ AICc $>2.0$. Although lagged prescribed fire area and wildfire incidence influenced the model fit for up to 10 and 8 years, respectively (data not shown), only 1 lagged year for prescribed fire and 3 for wildfire incidence were retained (Table 1), as these years provided the best predictive ability without over-fitting the model. ${ }^{1}$

Of the models evaluated for annual wildfire areal extent, previous-year prescribed fire, drought and their interaction were most important and accounted for $54 \%$ of the variation in annual wildfire areal extent (Table 2). KBDI performed better than PDSI as a drought index in both models. Neither ERC nor FWI accounted significantly for variation in annual wildfire incidence or areal extent and were dropped from the models. Surprisingly, past wildfire area burned was not significant in either the wildfire incidence or areal extent model, perhaps because the actual area burned by wildfire is much lower in comparison to that currently burned by prescribed fire and therefore may have less of an influence (see Figs $1 a$ and 1c).

The interaction detected between prescribed fire and drought in the wildfire areal extent model was evident in the wildfire incidence model as well, but was not significant. In both models, the influence of prescribed fire on wildfire was not constant across the range of drought indices observed over the 30 -year period. The highest number of wildfires occurred during drought years when antecedent year prescribed fire hectares were low (Fig. 2), suggesting that prescribed fire has less influence on wildfire during drought years.

\section{Discussion}

Prescribed fire is commonly used in fire-prone landscapes to reduce hazardous fuels and pre-empt wildfire effects, yet empirical information regarding the influence of prescribed fire on wildfire over long timespans is relatively rare in the literature. Although cause and effect is difficult to ascertain in
Table 2. Multiple regression model for wildfire areal extent Best fit model predicting annual wildfire areal extent ( $\log _{10}$ of wildfire ha) from prescribed fire, drought and their interaction. The functional form of the model is $Y=\beta_{0}+\beta_{1} X 1+\beta_{2} X 2+\beta_{3} X 3$, with an adjusted $R^{2}$ of 0.54 and $n=29 . X 1=$ previous-year prescribed fire ha (lag1); $X 2=$ current-year Keetch-Byram Drought Index, KBDI; $X 3=$ cross product, $(X 1-$ $9371.17) \times(X 2-276.49)$

\begin{tabular}{lclrr}
\hline Term & Coefficient, $\beta$ & Standard error & $t$-ratio & $P$-value \\
\hline Constant & 2.556 & 0.254 & 10.07 & $<0.0001$ \\
$X 1$ & -0.0000465 & 0.0000119 & -3.90 & 0.0006 \\
$X 2$ & 0.00319 & 0.000853 & 3.75 & 0.0009 \\
$X 3$ & 0.000000411 & 0.000000183 & 2.25 & 0.0331 \\
\hline
\end{tabular}

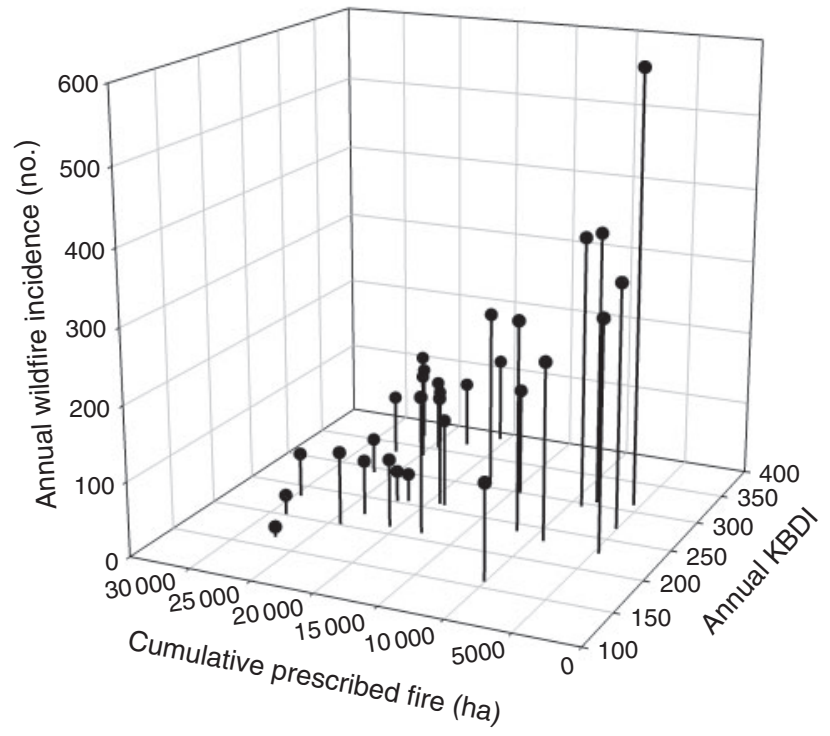

Fig. 2. Combined influence of cumulative prescribed fire (currentplus previous-year hectares burned) and current-year drought (KeetchByram Drought Index, KBDI) on current-year wildfire incidence at Fort Benning, GA.

observational data such as ours, we believe our study provides evidence of the cumulative effect of landscape-scale prescribed fire in reducing wildfire activity over time. Our results are consistent with other studies in the SE United States demonstrating the influence of previous fire (both prescribed fire and wildfire) on current wildfire ignitions and areal extent (Prestemon et al. 2002; Mercer and Prestemon 2005; Mercer et al. 2007), as well as studies from Australia (Fernandes and Botelho 2003; Boer et al. 2009) and Europe (Fernandes and Botelho 2003). Like Koehler (1992, 1993), our results highlight the importance of a sustained prescribed fire programme in

\footnotetext{
${ }^{1}$ The sign of the lagged wildfire incidence coefficient suggested a positive influence of previous wildfires on current wildfires, counter to that expected from the literature (Mercer and Prestemon 2005). We believe this relationship results from the overall decline in wildfire incidence over the 30-year record, whereby high wildfire incidence predicts subsequent high wildfire incidence early in the record and low wildfire incidence predicts subsequent low wildfire incidence later in the record, leading to an overall positive relationship. Despite the counterintuitive influence of lagged wildfire incidence, we retained it in the model because of its predictive ability, and to mitigate serial correlation.
} 
reducing and then maintaining low wildfire incidence across the landscape. This finding is particularly relevant in the SE United States, where recovery of fuels occurs relatively quickly, often within 3-5 years of prescribed fire (Davis and Cooper 1963; Brose and Wade 2002).

Drought is known to strongly influence wildfire activity and was a significant predictor of both wildfire incidence and areal extent in our study. Drought directly affects coarse woody fuel moisture, making fuels more available for ignition and combustion (Prestemon et al. 2013). Although prescribed fire may influence the relationship between drought and wildfire through fuels reduction, our results suggest some inevitability of wildfire during years of drought. Additionally, prolonged drought may decrease opportunities for prescribed fire, with cascading effects on wildfire occurrence in subsequent years (Mitchell et al. 2014). Surprisingly, we did not find a relationship between annual prescribed fire hectares and KBDI in our study $\left(r^{2}=0.03\right.$, data not shown), perhaps because prescribed fire tends to occur during the winter-spring season, whereas drought often occurs in the late spring and summer (Chan et al. 2004). A closer evaluation of within-year dynamics in prescribed fire, wildfire and drought may be useful in future analyses to further parse the influence of fuel treatments on wildfire activity at finer temporal scales. Evaluating spatial patterns of ignitions (e.g. based on forest types) and interactions with drought would provide a useful avenue for future analysis as well.

Although prescribed fire was a strong predictor of annual wildfire incidence, it did not explain as much of the variation in annual area burned by wildfire. Growth of fire after an ignition, and subsequent area burned, are influenced by several variables that we were unable to account for in our model. For example, response time of suppression crews and suppression tactics (e.g. back burning $v s$. direct attack) both influence the areal extent of wildfire and no data were available for these factors. Fuels and topography also highly influence fire spread rates (Brown and Smith 2000; Prestemon et al. 2013) and are not incorporated in our model due to lack of detailed information on fire locations over the 30-year record of our study. Lastly, reduced fuel loads across the Fort Benning landscape have enabled land managers to adopt a 'let burn' policy for wildfires within the last few years. Relationships between wildfire areal extent and prescribed fire are thus likely confounded by this wildfire management tactic as wildfires are allowed to spread when conditions are favourable to meet resource management objectives. This increased flexibility in managing wildfires, however, is one of the primary benefits of prescribed fire use at Fort Benning, and may explain the increase in wildfire area observed in the last 3 years of our record (Fig. 1c). ${ }^{2}$

Fire-adapted forests such as those at Fort Benning will likely burn by wildfire if not by prescribed fire. Prescribed fire offers a means of controlling the distribution of fire on the landscape both spatially and temporally, with benefits extending to smoke and emissions management as well (Hessburg and Agee 2003; North et al. 2012). Low-intensity surface fire also allows for carbon to be retained on the landscape in trees and other carbon stores, rather than emitted to the atmosphere in higher intensity wildfires (Hurteau and North 2009; Wiedinmyer and Hurteau 2010). Although in many fire-adapted forests mechanically reducing fuels is common practice, the rate of implementation is inadequate given the size of the forest area requiring treatment (North et al. 2012). Prescribed fire offers a means of effectively managing fuels over large areas. Although we demonstrate positive effects of prescribed fire in managing wildfire at Fort Benning, that effect may be undermined by prolonged drought, highlighting the need to prioritise prescribed fire to achieve maximum benefit during favourable years (Hiers et al. 2003; Price and Bradstock 2011; North et al. 2012; Mitchell et al. 2014). Nonetheless, because of treatment effectiveness in reducing wildfire activity and enabling wildfire use, prescribed burning offers managers flexibility in preparing for uncertain future climatic events such as drought, in addition to managing for current resource benefit.

\section{Acknowledgements}

We thank the numerous employees of Fort Benning's Land Management Branch and Conservation Branch that have been involved in fire management activities on the installation. We are particularly grateful to Jack Greenlee, Bob Larimore, Pete Swiderek and John Brent for supporting fire management and maintaining long-term fire records at Fort Benning. We thank Dan Chan of the Georgia Forestry Commission for help in gathering climate records, Jim zumBrunnen of Colorado State University's Statistics Department for advice regarding the statistical analysis, and Brian Waldrep for helpful input on an earlier version of the manuscript. The manuscript was greatly improved by the comments of two anonymous reviewers and the associate editor.

\section{References}

Boer MM, Sadler RJ, Wittkuhn RS, McCaw L, Grierson PF (2009) Longterm impacts of prescribed burning on regional extent and incidence of wildfires - Evidence from 50 years of active fire management in SW Australian forests. Forest Ecology and Management 259, 132-142. doi:10.1016/J.FORECO.2009.10.005

Bradshaw L, McCormick E (2000) FireFamily Plus User's Guide, Version 2.0. USDA Forest Service, Rocky Mountain Research Station, General Technical Report RMRS-GTR-67WWW. (Ogden, UT)

Brose P, Wade D (2002) Potential fire behavior in pine flatwood forests following three different fuel reduction techniques. Forest Ecology and Management 163, 71-84. doi:10.1016/S0378-1127(01)00528-X

Brown JK, Smith JK (2000) Wildland fire in ecosystems: effects of fire on flora. USDA Forest Service, Rocky Mountain Research Station, General Technical Report RMRS-GTR-42-vol.2. (Ogden, UT).

Burnham KP, Anderson DR (2002) 'Model Selection and Multimodel Inference: a Practical Information-Theoretic Approach'. 2nd edn. (Springer Verlag: New York, NY).

Butry DA, Prestemon JP, Abt KL, Sutphen R (2010) Economic optimization of wildfire intervention activities. International Journal of Wildland Fire 19, 659-672. doi:10.1071/WF09090

Chan DW, Paul JT, Dozier A (2004) Keetch-Byram Drought Index: can it help predict wildland fires? Fire Management Today 64, 39-42.

Chapman HH (1932) Is the longleaf type a climax? Ecology 13, 328-334. doi: $10.2307 / 1932309$

Countryman CM (1972) The fire environment concept. USDA Forest Service, Pacific Southwest Forest and Ranger Experiment Station, Technical Paper. (Berkeley, CA). Available at http://www.frames.

\footnotetext{
${ }^{2}$ Excluding the final 3 years of data (2010-12) from the analysis resulted in a decrease in $\Delta \mathrm{AICc} \sim 4.0$ and an increase in $R^{2}$ from 0.54 to 0.60 , suggesting an influence of these data points on the overall model, potentially reflecting Fort Benning's 'let burn' policy.
} 
gov/documents/behaveplus/publications/Countryman_1972_TheFire EnvironmentConcept_ocr.pdf [Verified 1 June 2015]

Davis LS, Cooper RW (1963) How prescribed burning affects wildfire occurrence. Journal of Forestry 61, 915-917.

Fernandes PM, Botelho HS (2003) A review of prescribed burning effectiveness in fire hazard reduction. International Journal of Wildland Fire 12, 117-128. doi:10.1071/WF02042

Finney MA, McHugh CW, Grenfell IC (2005) Stand- and landscape-leve effects of prescribed burning on two Arizona wildfires. Canadian Journal of Forest Research 35, 1714-1722. doi:10.1139/X05-090

Frost CC, Langley SK (2009) Historic fire regimes and presettlement vegetation of Fort Benning, Georgia. Report to the Fort Benning DPW Environmental Management Division (Fort Benning, GA).

Fulé PZ, Crouse JE, Roccaforte JP, Kalies EL (2012) Do thinning and/or burning treatments in western USA ponderosa or Jeffrey pine-dominated forests help restore natural fire behavior? Forest Ecology and Management 269, 68-81. doi:10.1016/J.FORECO.2011.12.025

Haywood JD (2009) Eight years of seasonal burning and herbicidal brush control influence sapling longleaf pine growth, understory vegetation, and the outcome of an ensuing wildfire. Forest Ecology and Management 258, 295-305. doi:10.1016/J.FORECO.2009.04.016

Hessburg PF, Agee JK (2003) An environmental narrative of Inland Northwest United States forests, 1800-2000. Forest Ecology and Management 178, 23-59. doi:10.1016/S0378-1127(03)00052-5

Hiers JK, Laine SC, Bachant JJ, Furman JF, Green WW, Jr, Compton V (2003) Spatial modeling tools for prioritizing prescribed burning activities at the landscape scale. Conservation Biology 17, 1571-1578. doi:10.1111/J.1523-1739.2003.00381.X

Hurteau M, North M (2009) Fuel treatment effects on tree-based forest carbon storage and emissions under modeled wildfire scenarios. Frontiers in Ecology and the Environment 7, 409-414. doi:10.1890/080049

Keetch JJ, Byram GM (1968) A drought index for forest fire control. USDA Forest Service, Southeastern Forest Experiment Station, Research Paper SE-38. (Asheville, NC).

Koehler JT (1992-1993) Prescribed burning: a wildfire prevention tool? Fire Management Notes 53-54, 9-13.

Marshall DJ, Wimberly M, Bettinger P, Stanturf J (2008) Synthesis of knowledge of hazardous fuels management in loblolly pine forests USDA Forest Service, Southern Research Station, General Technical Report SRS-110. (Asheville, NC).

McCaw WL (2013) Managing forest fuels using prescribed fire - A perspective from southern Australia. Forest Ecology and Management 294, 217-224. doi:10.1016/J.FORECO.2012.09.012

Mercer DE, Prestemon JP (2005) Comparing production function models for wildfire risk analysis in the wildland-urban interface. Forest Policy and Economics 7, 782-795. doi:10.1016/J.FORPOL.2005.03.003

Mercer DE, Prestemon JP, Butry DT, Pye JM (2007) Evaluating alternative prescribed burning policies to reduce net economic damages from wildfire. American Journal of Agricultural Economics 89, 63-77. doi:10.1111/J.1467-8276.2007.00963.X

Mitchell RJ, Hiers JK, O’Brien JJ, Starr G (2009) Ecological forestry in the Southeast: understanding the ecology of fuels. Journal of Forestry 107, 391-397.

Mitchell RJ, Liu Y, O’Brien JJ, Elliott KJ, Starr G, Miniat CF, Hiers JK (2014) Future climate and fire interactions in the southeastern region of the United States. Forest Ecology and Management 327, 316-326. doi:10.1016/J.FORECO.2013.12.003

North M, Collins BM, Stephens S (2012) Using fire to increase the scale, benefits, and future maintenance of fuels treatments. Journal of Forestry 110, 392-401. doi:10.5849/JOF.12-021

Palmer WC (1965) Meteorological drought. US Department of Commerce Weather Bureau, Research Paper 45 (Washington DC).

Prestemon JP, Pye JM, Butry DT, Holmes TP, Mercer DE (2002) Understanding broadscale wildfire risks in a human-dominated landscape. Forest Science 48, 685-693.

Prestemon JP, Hawbaker TJ, Bowden M, Carpenter J, Brooks MT, Abt KL, Sutphen R, Scranton S (2013) Wildfire ignitions: a review of the science and recommendations for empirical modeling. USDA Forest Service, Southern Research Station General Technical Report SRS-171. (Asheville, NC).

Price OF, Bradstock RA (2011) Quantifying the influence of fuel age and weather on the annual extent of unplanned fires in the Sydney region of Australia. International Journal of Wildland Fire 20, 142-151. doi:10.1071/WF10016

Prichard SJ, Kennedy MC (2014) Fuel treatment and landform modify landscape patterns of burn severity in an extreme fire event. Ecological Applications 24, 571-590. doi:10.1890/13-0343.1

Pyne S (1982) 'Fire in America: A Cultural History of Wildland and Rural Fire'. (Princeton University Press: Princeton, NJ).

Schwilk DW, Keeley JE, Knapp EE, McIver J, Bailey JD, Fettig CJ, Fiedler CE, Harrod RJ, Moghaddas JJ, Outcalt KW, Skinner CN, Stephens SL, Waldrop TA, Yaussy DA, Youngblood A (2009) The national Fire and Fire Surrogate study: effects of fuel reduction methods on forest vegetation structure and fuels. Ecological Applications 19, 285-304. doi:10.1890/07-1747.1

Stephens SL, McIver JD, Boerner REJ, Fettig CJ, Fontaine JB, Hartsough BR, Kennedy PL, Schwilk DW (2012) The effects of forest fuelreduction treatments in the United States. Bioscience 62, 549-560. doi:10.1525/BIO.2012.62.6.6

Stephens SL, Agee JK, Fulé PZ, North MP, Romme WH, Swetnam TW, Turner MG (2013) Managing forests and fire in changing climates. Science 342, 41-42. doi:10.1126/SCIENCE.1240294

Stoddard HL (1931) 'The Bobwhite Quail: its Habits, Preservation, and Increase'. (Charles Scribner's Sons: New York, NY).

USAIC (US Army Infantry Center) (2006) Integrated natural resources management plan, Fort Benning army installation, 2006 incremental revision. Directorate of Public Works, Environmental Management Division (Fort Benning, GA).

USDA (US Department of Agriculture) Forest Service (2000) Protecting people and sustaining resources in fire-adapted ecosystems: a cohesive strategy. Available at http://www.fs.fed.us/publications/2000/cohesive strategy 10132000.pdf [Verified 23 September 2014].

Westerling AL, Hidalgo HG, Cayan DR, Swetnam TW (2006) Warming and earlier spring increase western U.S. forest wildfire activity. Science 313, 940-943. doi:10.1126/SCIENCE.1128834

Wiedinmyer C, Hurteau MD (2010) Prescribed fire as a means of reducing forest carbon emissions in the western U.S. Environmental Science \& Technology 44, 1926-1932. doi:10.1021/ES902455E 